\title{
German Trauerspiel and Its International Nexus: On the Migration of Poetic Forms
}

\author{
Joel B. Lande
}

\section{Generic Status of German Trauerspiel}

Generic terms are, of necessity, not idiosyncratic. In order to execute the task of classifying multiple individual poetic objects, they must possess a sufficient degree of generality. ${ }^{1}$ Such classification is not a value-neutral activity: employment of generic categories ennobles at the same time that it orders, setting up lines of filiation between the venerated forms of antiquity and the present moment. Deviation from established onomastic conventions risks disconnecting the tether to the past and interrupts the invocation of authority. An exception to this rule within the history of early modern European poetry is seventeenth-century German Trauerspiel or, as it has come to be called in the English context, 'play of mourning' and 'tragic drama'. While English speakers have labored to find a distinctive rendering for the usually unproblematic term Trauerspiel, scholars writing in German still today associate Trauerspiel with the so-called 'Kunstdrama' written by a select group of playwrights. These lexical oddities, along with the influential reception of Walter Benjamin's habilitation, especially within the Anglo-American context, participate in the widespread belief in an early modern German tradition irreducibly different from its European counterparts. ${ }^{2}$ The aspiration to uniqueness, the desire to carve out a unique tradition of Trauerspiel, served to elevate rather than denigrate the status of the genre. And yet, as the scholarship has amply demonstrated, the claim to singularity set forth in Benjamin's Trauerspiel-book itself emerged from a scholarly landscape littered with attempts at uncovering a

1 In order to avoid the question whether the texts I focus on this essay count as literature in the emphatic sense this term is used today, I use the conventional term of the seventeenthcentury - poetry - to refer to, at a minimum, drama, epic, and lyric.

2 See Walter Benjamin, Ursprung des deutschen Trauerspiels, in Walter Benjamin, Gesammelte Schriften, ed. Rolf Tiedemann and Hermann Schweppenhäuser (Frankfurt am Main: Suhrkamp Taschenbuch Wissenschaft, 1991), vol. 1/1, pp. 203-430. 
distinctly German literary heritage. ${ }^{3}$ Benjamin's study was directed against contemporaries who affiliated the German Baroque with the larger European Renaissance and its inheritance of the ancients as well as against those who advanced what Benjamin regarded as a wrongheaded conception of a German literary heritage. The terminological anomalies mentioned above are the effect of this attempt to isolate and thereby heighten the status of the plays written by a small group known as the Silesian School, especially the plays of Andreas Gryphius (1616-1664) and Daniel Caspar von Lohenstein (1635-1683). Since the early twentieth century, a formidable body of scholarship has emerged, with its attention focused squarely on the connections between the plays of these two figures and the major political and theological controversies of the seventeenth century. Throughout this time, the denominations have been firm: Baroque and not Renaissance, Trauerspiel and not Tragödie. With that, the connection to the contemporaneous European world of letters has been dissevered and the communion with ancient paradigms disturbed.

\section{Rethinking Trauerspiel—German Lands and the Dutch Republic}

As the historical conditions of Benjamin's own study, including the contextual factors that contributed to his search for a distinctly German tragic tradition, have been unearthed, the belief in an idiosyncratically German Trauerspiel has persisted. There are, however, sound reasons for resisting a wholesale acceptance of this view and for rethinking just how idiosyncratic Trauerspiel is. In the following, I deal with a body of texts that bear the name Trauerspiel but that superficially appear to be translations from another European vernacular. As such, they seem to endanger any claim to the purity of the genre. The fact of the matter is that Trauerspiel emerged through contact with other existing European poetic forms, past as well as contemporaneous. If the genre emerged into something unique-and I submit that it did - then it did so within a matrix that contained both the appropriation of alien forms and autochthonous developments. Many plays were brought into the German language and context, and in the act of importation were shot through with insertions and modifications that often radically altered their shape and meaning.

3 Jane O. Newman, Benjamin's Library: Modernity, Nation, and the Baroque (Ithaca: Cornell University Press, 2011). 
I wish to focus on two sets of examples. My claim is that the emergence of Trauerspiel in the mid-seventeenth century depended upon a unique inflection of a traditional generic category, but this inflection drew on channels of communication that stretched beyond the German-speaking territories. In keeping with the general theme of this volume, my essay takes its start from and circles back repeatedly to the great Dutch poet Joost van den Vondel (1587-1679), whose contemporary European reception was most pronounced in the German-speaking territories. The circulation and redeployment of Vondel's texts in German contexts is particularly remarkable because we are dealing here with traffic between two poetic vernaculars. Exchange of knowledge across Europe was commonplace within the Respublica literarum or Republic of Letters; in this domain, the shared knowledge and use of the Latin language facilitated mutual intelligibility. ${ }^{4}$ Although Dutch was spoken only in the remote yet commercially influential corner of Europe, its poetry played a very significant role in the broader European landscape. That this relatively minor tongue had such purchase in the instances that will concern me in this essay was surely enabled by the Republic, by the common educational roots and shared commitment to Latin letters. ${ }^{5}$ The plays I am concerned with, however, were not written in Latin, but in German and Dutch. Linguistic traffic across the Dutch-German border played a decisive historical role for the Germans, whose epoch-making project of establishing a poetic language drew much of its energy from the Dutch. ${ }^{6}$ Even though my focus in this essay shall be drama, a strong case could also be made for the influence of Dutch lyric in the German setting. For Germans, the more advanced neighbors to the northwest, with whom they shared linguistic kinship, were a source of inspiration and of textual material.

There is good reason to take the Dutch-German nexus seriously. Among the many connections, I wish to identify two in a preliminary fashion. First are the English traveling theatrical troupes that made their way through Dutch and Northern German territories during the final decade of the sixteenth and early decades of the seventeenth century. They brought with them not just Shakespeare's plays (among others), but also a stage fool named Pickelhering. In both

4 Anthony Grafton, Worlds Made by Words (Cambridge: Harvard University Press, 2009).

5 Tom Deneire (ed.), Dynamics of Neo-Latin and the Vernacular: Language and Poetics, Translation and Transfer (Leiden and Boston: Brill, 2014), esp. the introduction by Deneire, pp. 1-17. Additional references can be found in this volume.

6 Ulrich Bornemann, Anlehnung und Abgrenzung: Untersuchungen zur Rezeption der niederländischen Literatur in der deutschen Dichtungsreform des siebzehnten Jahrhunderts (Assen: Van Gorcum, 1976). 
the Dutch and German contexts, this fool-figure remained a mainstay of the stage over subsequent decades, long after his English roots had passed into oblivion. ${ }^{7}$ At the same time, there were Dutch acting troupes, influenced by the English, who traveled through northern German territories. ${ }^{8}$ The overlap between the Dutch and German context is evident in the many surviving plays from across the seventeenth century featuring a stage fool of the name Pickelhering, but also in paintings such as the Frans Hals's 'Peeckelhaeringh' from ca. $1628-1630 .{ }^{9}$ The second point of contact is more immediately relevant to the foregoing remarks on genre. The Dutch humanist tradition exercised an unparalleled influence on German poetry, especially during the first half of the seventeenth century. Nearly a quarter of the students enrolled at the university of Leiden during this period were German-speakers on their perergrinatio academica. ${ }^{10}$ The impact of the Dutch university can be most powerfully felt in the writings of Martin Opitz (1597-1639), who studied in Leiden under the eminent humanist Daniel Heinsius (1580-1655), and remained a loyal champion of his teacher as both a theoretician and poet.1 ${ }^{11}$ Through his own translations, original poems, and treatises, Opitz pioneered the almost century-long efforts to elevate the German language to equal standing with its European neighbors. The close affinity between the two languages as well as the Dutch humanist tradition formed the foundation of Opitz's reform endeavors. ${ }^{12}$

I address these developments at greater length in my forthcoming study, The Persistence of Folly, currently in manuscript.

8 Emil Herz, Englische Schauspieler und englisches Schauspiel zur Zeit Shakespeares in Deutschland (Hamburg: Verlag Leopold Voß, 1903). For a collection of such plays, see Manfred Brauneck, Spieltexte der Wanderbühne (Berlin: De Gruyter, 1970-2007), 5 vols. in 6.

10 Bornemann, Anlehnung und Abgrenzung, pp. 11-18.

11 Bornemann, Anlehnung und Abgrenzung, pp. 18-42.

12 See Gunter E. Grimm, Literatur und Gelehrtentum in Deutschland (Tübingen: Max Niemeyer Verlag, 1983). For a more recent and more detailed consideration of these themes, see Guillaume van Gemert, 'Vom Aristarchus zur Jesuiten-Poesie: Zum dynamischen Wechselbezug von Latein und Landessprache in den deutschen Landen in der Frühen Neuzeit / From Aristarch to Jesuit Poetry: The Shifting Interrelation between Latin and the Vernacular in the German Lands in Early Modern Times', in Jan Bloemendal (ed.), Bilingual Europe: Latin and Vernacular Cultures, Examples of Bilingualism and Multilingualism c. 1300-1800 (Leiden and Boston: Brill, 2015), pp. 118-143. 


\section{German 'Trauerspiel' and the Dramatic Oeuvre of Joost van den Vondel}

Much like Opitz, the plays that stand in the focus of this essay turn to the Dutch context as the foundation for their own forays into the newly emerging world of German poetry. Almost every play refers to itself as writing 'according to' or 'after' the Dutch plays written by Vondel. The German word they use to refer to their writing practice, nach, admits of both these meanings: it can refer to the more closely hewn linguistic interchange from Dutch to German and the more loosely construed adaptation. The one exception to this rule, which claims to be 'out of' or 'from' (aus) Vondel's Dutch text still takes significant liberty with its source material. I belabor this seemingly minor point because the plays at stake in this essay all operate with what I wish to call a weak conception of authorial propriety. By weak authorial propriety I mean, firstly, that there was no sense that Vondel's plays were cemented in the shape he published them and, secondly, that there was not a tacit imperative to maintain fidelity to the plays as Vondel published them. To write after or according to Vondel is to feel free to insert and excise, to appropriate and transform, at will. The German plays I discuss in this essay employ a distinct practice of writinga writing out of, after, and according to - that allows for the use of Vondel's name of the frontispiece of plays that retain very little just as well as on plays that retain essentially all the contents of Vondel's original play. No text that I am dealing with thinks of itself as a translation as we would employ the word; none evinces anxiety about living up to the intentions of the original author; none feels beholden to reproducing the compositional unity of Vondel's plays.

In examining the various plays that bear the name Vondel with the corpus of seventeenth-century German Trauerspiel, one is not examining the (better or worse) translations of an author in the usual sense. However naturally attractive and readily accessible concepts like author and translations may seem, they fail to capture the practice these writers are engaged in and the use to which they were putting Vondel's plays. Within this practice and use, Vondel functions more as a template. I prefer the term template because his plays were added to, subtracted from, expanded and truncated as they were being transferred to a different linguistic and cultural setting. Thinking of Vondel as a template has the additional advantage of avoiding the normative dismissals that many of the German plays I deal with have garnered. Because these texts have been treated as translations of an original drama, they have been subject to evaluations that operate with the distinction between greater or lesser accuracy. In working with the concept of a template, by contrast, one has a significantly more flexible heuristic: this writing format admits of, indeed depends 
for its life upon, alterations of all sorts. What is more, the quality of a template is, in general, assessed in terms of its utility-which is to say in terms of its capacity to serve as an instrument for bringing forth something different from itself. In the following I therefore speak of modifications and adaptations made to the Vondel template and not translations and deviations from Vondel's text.

Some of the template, especially its rudimentary formal features, is immediately evident. For instance, the use of choral passages - called Rey in Dutch and Reyen in German — was drawn from neoclassical Dutch tragedy and gained a life of its own within the German context, assuming highly unusual allegorical and even cosmological shapes in later plays. ${ }^{13}$ The same could be said of use of stichomythia, of line-by line verbal battles. Such passages, a conventional feature of Ancient Greek and Roman tragedy also appropriated by Vondel and his contemporaries, were expanded to an almost exhausting degree and became the key formal technique for articulating the central conflict in German Trauerspiel. One literary historian has gone so far as to call Gryphius's first original tragedy, Leo Armenius, an 'overgrowth of stichomythia' ('Auswucherung der Stichomythien'). ${ }^{14}$ This expansive trend continued through Lohenstein's last play Sophonisbe (1680). Such developments illustrate the contingent effects that can emerge when conventions from one context are appropriated in another; forms deviate from their original path and are taken in unanticipated directions. Even when considering such manifest formal debts, one sees that transfer is not a frictionless enterprise; the choral passages and verbal back-and-forths become something different-and stranger, less overtly classicizing —in Trauerspiel. Attention to the roots and the divergent ramifications of Dutch classical drama in seventeenth-century German drama helps to lend greater precision to one of the key strategies by means of which the generic distinctness of Trauerspiel has been established in the scholarship: the claim to its non-Aristotelian design. It would be more accurate to say, in light of the manifest influence of Dutch neoclassical tragedy on the Germans, that Trauerspiel comes into being on the basis of a neo-Aristotelian template, but perpetuates itself in the untroubled and unwitting manipulation of Aristotelian conventions.

In looking at the various deployments on the Vondel template, I shall consider the periphery of what is usually treated in discussions of Trauerspiel. My goal is not to redeem these as unacknowledged literary masterpieces, but

\footnotetext{
13 This is particularly evident in the plays of Daniel Caspar von Lohenstein.

14 Gerhard Kaiser, 'Leo Armenius, Oder Fürsten=Mord', in Gerhard Kaiser (ed.), Die Dramen des Andreas Gryphius: Eine Sammlung von Einzelinterpretationen (Stuttgart: J.B. Metzler Verlag, 1968), pp. 3-34, esp. p. 3 .
} 
instead to draw out the way that Trauerspiel comes into being as an appropriated but transformed genre, one that in the act of migration discloses new possibilities for the reproduction of forms and the production of meaning. And in focusing on the lines of filiation stretching back from Trauerspiel to Dutch drama, my goal is not to undercut but instead alter the shape of the claim to the uniqueness of German Trauerspiel in the seventeenth century. Much like many other instances in the history of European poetic and artistic forms, Trauerspiel made its claim to legitimacy on the basis of an already established and ennobled genre, namely the Dutch neo-classical Treurspel. Central to the formation of German Trauerspiel, it turns out, is the appropriation and modification of a positively valorized template-Vondel, in this case. Trauerspiel, one might say, is marked out by fuzzy and porous boundaries, where the migration across national, linguistic, and cultural boundaries - the circulation of genres across Europe-brings along with it alteration and mutation. This zone-where to write is to write out of, after, and according to—does not allow for a clear-cut division between invention and imitation.

\section{Case 1: Gryphius's Die sieben Brüder and Vondel's Gebroeders}

The natural point of ingress for any consideration of the connection between seventeenth-century Dutch and German drama is the figure of Andreas Gryphius. ${ }^{15}$ Beginning with Gryphius has the distinct advantage of showing the scope of the uses that were made of the Vondel template. In his wake, others took up work with the same material, but modified the template further than their predecessor Gryphius had. The process of appropriation and transformation entails changes not just to the formal arrangement of the template, but also to its thematic focus.

Gryphius greatly admired Vondel, and may have well encountered his plays both in print and at the newly opened Amsterdam theater during his student days in Leiden (1638-1644). ${ }^{16}$ Although not printed until after his death but

15 Among the more recent articles that touch on many of the issues I discuss in this essay, see Ferdinand van Ingen, 'Die Übersetzung als Rezeptionsdokument: Vondel in DeutschlandGryphius in Holland', Michigan Germanic Studies 4 (1978), 131-164; Guillaume van Gemert, 'Between Disregard and Political Mobilization-Vondel as a Playwright in Contemporary European Context: England, France and the German lands', in Jan Bloemendal and FranzWillem Korsten, Joost van den Vondel (1587-1679): Dutch Playwright in the Golden Age (Leiden and Boston: Brill, 2012), pp. 171-198.

16 See Willi Fleming, 'Vondels Einfluss auf die Trauerspiele des Andreas Gryphius, Zugleich 
probably completed in the early 1640s, Gryphius's adaptation of Vondel's 1640 Gebroeders constitutes his first foray into the field of drama. ${ }^{17}$ As scholars have long noticed, Vondel made an indelible mark on Gryphius own language and imagery, as turns of phrase and individual passages from the Dutch writer reappear even in Gryphius's later plays. His rendering of Gebroeders, meanwhile, adheres so closely to the Dutch text on a linguistic level that it often stretches the limits of comprehensibility. Despite this challenge, it was performed at least five times in the school theater in Breslau in $165^{2 .}{ }^{18}$

The selection of this play, in particular, for translation is puzzling. Gebroeders comes at a transitional moment in Vondel's career, when he is giving up the conventions of Senecan tragedy and increasingly adopting classical Greek models. The importance of classical Greek poetry is evident from the dedication to the Amsterdam humanist Gerardus Vossius (1577-1649), under whose influence Vondel translated Sophocles' Electra, and deepened his understanding of Aristotle's Poetics. ${ }^{19}$ The perplexity goes even deeper since Gryphius, disregarding or perhaps unaware of this philhellenic turn, omits the dedication and inserts a prologue that draws on Seneca's Thyestes and Agamemnon. ${ }^{20}$ In a scene that echoes the appearance of the ghosts of Tantalus and Thyestes at the two aforementioned Seneca plays, Gryphius commences his adaption of Vondel, Die Sieben Brüder oder Die Gibeoniter, with a prefatory monologue delivered by the bloody ghost of King Saul. ${ }^{21}$ And much like these two figures, Saul appears on the stage to bemoan his eternal torture and introduce the curse that hangs over his house and progeny. And in a final gesture toward Senecan

eine methodologische Besinnung', Philologus 13 (1928), pp. 184-196. For a close consideration of the linguistic coincidences in the Vondel translation, see Henri Plard, 'Die sieben Brüder / Oder Die Gibeoniter' in Kaiser, Die Dramen des Andreas Gryphius, pp. 305-317.

17 The exact timeline of Gryphius's work on the play remains uncertain. It was only published after his death by his son Christian, who provides no direction in this regard.

18 Plard, 'Sieben Brüder / Oder Die Gibeoniter', p. 317.

19 See Kåre Langwik Johannessen, Zwischen Himmel und Erde: Eine Studie über Joost van den Vondels biblische Tragödie in gattungsgeschichtlicher Perspektive (Fredrikstad: Universitetsforlaget, 1963), pp. 114-115. See also W.A.P. Smit, Van Pascha tot Noah. vol. 1: Van Pascha tot Leeuwendalers (Zwolle: Tjeenk Willink, 1956), pp. 265-302.

20 In truth, he incorporates many of the elements from Vondel's dedication into Saul's monologue. For instance Vondel lists Saul's great shortcoming as his 'ongehoorzaemheid', while in Gryphius's prologue Saul says of himself that he must eternally repent for 'den ungehorsam' he committed. Similarly, Vondel blames Saul for 'meineedigheit', while Saul says in Gryphius that he is guilty of 'Meineid'. This list could be extended.

21 Reprinted in Andreas Gryphius, Gesamtausgabe der deutschsprachigen Werke, ed. Hugh Powell (Tübingen: Max Niemeyer Verlag, 1966), vol. 6, pp. 71-129. 
tragedy, Saul also completes his speech as the sun rises and he must flee the stage. Of course, Seneca figured centrally in the humanistic educational program and exercises a massive influence on tragic forms across Europe. ${ }^{22}$ There is no evidence in Gryphius's oeuvre that he objected to or even recognized the significance of the Dutch revival of Ancient Greek sources in Vondel. However, it is certain that he felt a strong affinity with Seneca's tragedy. In his adaptation of Vondel as well as in all of his later plays the influence of Roman tragedy is pervasive.

Gryphius's insertion of a Senecan prologue scene spoken by Saul points to a general feature in the evolution of poetic forms. The migration of a poetic form across cultural and linguistic boundaries allows for reassignment of their strategic import. After all, poetic texts are not simply spontaneous expressions, but in many cases inhabit a cultural place within a pre-established set of concerns to which they respond. A new field of circulation brings along with it new pre-existing conditions and concerns, statements and responses. To put the same point more concretely, the significance of Vondel's Gebroeders is determined in no small part by the changing tides of Roman and Greek influence at the time as well as the political setting of the Dutch Republic. Much of the Dutch controversy is lost on Gryphius and has even less impact on the subsequent engagements with the German text. When the play is deracinated from its native context, including the controversies and debates concerning the relationship of Dutch Treurspel to Ancient Greek tragedy, it assumes a new place and purpose. For example, any of the most intensely debated issues in Dutch letters at the time are Aristotelian in provenance, including the unity of plot and the necessity of catharsis. ${ }^{23}$ But these controversies become flattened when transferred to the German setting and instead take on a life entirely of their own, both in the domain of written dramas and poetic treatises. Just as Gryphius here alters Vondel's play, the long lineage of poetological treatises in the seventeenth century-from Opitz to Harsdörffer to Omeis-drew on while simultaneously transforming treatises emerging from the Dutch humanist tradition, including Heinsius and Vossius as well as their Italian antecedents. ${ }^{24}$

For the German context in particular, see Paul Stachel, Seneca und das deutsche Renaissancedrama: Studien zur Literatur- und Stilgeschichte des 16. und 17. Jahrhunderts (Berlin: Mayer \& Müller, 1907).

23 The developments of the concept of catharsis has been traced with significant erudition in Hans-Jürgen Schings, 'Consolatio Tragoediae: Zur Theorie des barocken Trauerspiels' in Reinhold Grimm (ed.), Deutsche Dramentheorien (Wiesbaden: Akademische Verlagsgesellschaft Athenaion, 1978), vol. 1, pp. 1-44. 
When concepts like catharsis and entire genres like tragedy were brought into the German context, they do not remain the same, but link up with Lutheran theology as well as contemporary political debates. ${ }^{25}$ As the Aristotelian provenance of concepts and the neo-classical orchestration of dramatic form fade into oblivion, catharsis becomes identified with the Christian concept of consolatio and the Aristotelian demand that the tragedy focus on a figure of middling moral stature is supplanted by an interest in moral perfection like the martyr and extreme moral corruption like the tyrant. ${ }^{26}$ Or, to return to an example I gave above, the neo-classical choral passages shed their traditional shape and morph into allegorical passages of with cosmological dimensions. These sorts of changes unfold within a process of appropriation and redeployment which themselves solicit further responses and unforeseeable transformations, and it is by these means that Trauerspiel became 'such an unaristotelian product. $^{27}$

In the case of Gryphius's Die sieben Brüder, the migration of form from the Dutch to the German context went hand-in-hand with the imposition of a new thematic focus. Whereas the Biblical passages upon which the play is based, ${ }_{2}$ Samuel 21, 1-14, as well as Book VII, ch. 12 of Josephus's Antiquities of the

on the rhetorical tradition Ludwig Fischer, Gebundene Rede: Dichtung und Rhetorik in der literarischen Theorie des Barock in Deutschland (Tübingen: Max Niemeyer Verlag, 1968); Joachim Dyck, Ticht-Kunst: Deutsche Barockpoetik und rhetorische Tradition (Tübingen: Max Niemeyer Verlag, 1969).

25 The latter issue in particular has been the topic of much research since Walter Benjamin's first attempt to link Trauerspiel to Carl Schmitt's theory of political sovereignty. See for instance Albrecht Koschorke, Thomas Frank, Ethel Matala de Mazza, and Susanne Lüdemann, Der fiktive Staat: Konstruktionen des politischen Körpers in der Geschichte Europas (Frankfurt am Main: Fischer Taschenbuch Verlag, 2007), pp. 103-218; Armin Schäfer, 'Der Souverän, die clementia und die Aporien der Politik: Überlegungen zu Daniel Casper von Lohensteins Trauerspielen', in Erika Fischer-Lichte (ed.), Theatralität und die Krisen der Repräsentation (Stuttgart: J.B. Metzler Verlag, 2001), pp. 101-124; and Armin Schäfer, 'Die Wohltat in der Politik: Über Souveränität und Moral im barocken Trauerspiel', in Anne von der Heiden (ed.), Per imaginem: Bildlichkeit und Souveränität (Zürich: Diaphanes, 2005), pp. 79-99.

26 This is Benjamin's thesis that there is a Janus face to tragedy, which seems to me by large stretches correct. Of course, there are other models of extreme moral corruption, but the tyrant is certainly a prominent one. See Benjamin, Ursprung des deutschen Trauerspiels, p. 249.

27 Schings, 'Consolatio Tragoediae: Zur Theorie des barocken Trauerspiels', p. 1. Although Schings makes this remark in reference to the martyr play in particular, his essay goes on to lend general plausibility to the initial and more limited claim. 
Jews, identify Saul's disobedience of God as source of his punishment, the final installment of which is the hanging of seven of his male descendants, Gryphius uses the prologue to install a political frame. In his prologue, Saul appears as something other than a king who is robbed of God's good favor for his insubordination; he is a bloodthirsty tyrant. In reframing the story underlying the drama, Gryphius adduces a political purpose utterly alien to Vondel's text and its political environment. The programmatically significant lines spoken in the prologue by Saul warrant quoting:

\section{Zum Spiegel euch / blutdürstige Tyrannen/ \\ Die ihr nur tödten könt / und bannen/ \\ Schaut / Schaut / die immer frische Wund ist trieffend blieben / \\ Durch die ich mich in höchste Noth getrieben. ${ }^{28}$}

(A mirror for you, bloodthirsty tyrants

Who only know to kill and banish

Look, look, the still dripping ever-fresh wound

Through which I drove myself to the most extreme exigency.)

Saul here suggests a purpose to his presence onstage and a lesson that can be drawn from his miserable fate. The idea that tragedy should serve as a speculum had made a prominent appearance in the Martin Opitz's remarks on tragedy. In the introduction to his translation of Seneca's Trojan Women, Opitz remarks that 'tragedy $[. .$.$] is nothing more than a mirror of all those who rely on for-$ tune alone in all their doings.' ('Dann eine Tragödie $|[\ldots]|$ ist nichts anders als ein Spiegel derer $\mid$ die in allem jhrem thun vnd lassen auff das blosse Glück fussen.'). ${ }^{29}$ Opitz means by this that tragedy concentrates in general on figures who fail to employ a proper moral compass to guide their actions; relying instead upon their own arbitrary passions and will, tragic figures ultimately are vulnerable to the unforeseeable accidents of a fate they do not command. Gryphius, by contrast, further limits the set of human fates reflected in his speculum. Saul does not address his fate to just anyone; he singles out an infamous ilk of political rulers, the tyrants, for his tragedy. Gryphius transforms the story of Saul's disobedience of God and his eventual condemnation, recounted in 1 Samuel 15-16, into an act of political misconduct. In so doing, Gryphius aims

\footnotetext{
28 Gryphius, Gesamtausgabe der deutschsprachigen Werke, vol. 6, p. 76.

29 See Martin Opitz, Weltliche Poemata (Tübingen: Max Niemeyer Verlag, 1967; reprint of fourth edition from 1644), vol. 1, p. 314.
} 
to draw out the moral dimension of political action, to show the inseparability of political and moral mandates. Tyranny, for Gryphius, is as much a vice as it is a political perversion. It is not so much that Gryphius abandons the Biblical story of Saul's rebellion against God as that he takes such rebellion against God as the proper characterization of bloodthirsty tyrant's moral failure. To be a politically transgressive tyrant is to abandon God's moral mandates. While the verses in 2 Samuel 21 had indicated that Saul's house is sullied for his massacre of the Gibeonites, against the command of God, Gryphius translates these passages into a political terminology alien to the Biblical text, firmly rooted in the central controversies of political thought in the mid-seventeenth century.

By contrast with Vondel's own emphasis in his dedication to Vossius that the play should serve a proof of God's punishment of evil-doers and a lesson in the necessity to fear God, Gryphius casts the entire play as a lesson in the ills of political malfeasance. In conceiving of Saul as a paradigmatic political tyrant, Gryphius introduces two interconnected thematic elements that prove of the essence to the Trauerspiele he begins publishing in 1650 . Firstly, he introduces the theme of the violent excesses to which the tyrant is prone. And, secondly, he places these within an explicitly moral and eschatological framework. The emphasis on the pitfalls of a political rationality segregated from morality is at the heart of essentially all Gryphius's tragedies, from Leo Armenius (1650) through Papinian (1659). In positioning the tyrant as the enemy of morality, Gryphius inserts himself into one of the key contemporary debates in political philosophy and jurisprudence. One of the guiding concerns in political thought of the seventeenth century was whether political actions possess a distinct set of ends that could be assessed independent of a moral perspective. The key term, Staatsräson, was associated originally with Machiavelli's The Prince (1532), but in the course of the seventeenth century was subject to a broad swath of different elaborations, with proponents as well as opponents. ${ }^{30}$ Whereas the term 'Machiavellismus' was, with a few exceptions, used in a derogatory sense, there were systematic attempts to develop a theory of a political rationality that was compatible with religious virtue. ${ }^{31}$ Trauerspieland in particular Gryphius's Trauerspiel—inveighs against the employment

30 See the excellent survey of the historical field in Horst Dreitzel, 'Neostoizismus, Tacitismus, Staatsräson' in Friedrich Ueberweg (ed.), Die Philosophie des 17. Jahrhunderts (Basel: Schwabe \& Co Verlag, 2001), vol. 4/1, pp. 694-714.

31 Michael Stolleis, 'Machiavellismus und Staatsräson: Ein Beitrag zu Conrings Politischem Denken', in Michael Stolleis (ed.), Hermann Conring (1606-1681): Beiträge zum Leben und Werk (Berlin: Duncker \& Humblot, 1983), pp. 173-199. 
of a political rationality detached from moral considerations; inevitably, the reliance on political reasons alone exerts a violent and destructive force. ${ }^{32}$

The focus on political rationality in Gryphius's prologue constituted one level within a two-tiered design. The prologue's address to tyrants is counterbalanced by very brief epilogue that generalizes the intended addressee. After the main action of the play as Vondel conceived it is complete, Gryphius calls Saul back onto the stage to say: 'Man! O reflect yourself in me; what struck me also threatens you.' ('Mensch! O spiegel dich an mir / was mich schlug / das dreuet dir'.) $)^{33}$ The key thought here is that the significance of Saul's moral failure is relevant to a broader scope of persons than just tyrants. The inclusion of this epilogue - and its generalization of the speculum - fits with a model of the applicability and utility of tragedy described by Opitz:

In dem wir grosser Leute / gantzer Stätte vnd Länder eussersten Untergang zum offern schawen vnd betrachten / tragen wir zwar / wie es sich gebüret / erbarmen mit jhnen / können auch nochmals auß Wehmuth die Thränen kaum zurück halten; wir lernen aber darneben auch durch stetige Besichtigung so vielen Creutzes und Ubels das andern begegnet ist / das vnsrige / welches vns begegnet möchte / weniger fürchten und besser erdulden.

(When we often see and behold the extreme downfall of powerful people, entire cities and lands, we feel the appropriate pity for them and out of woefulness can barely hold back the tears. Simultaneously, however, we also learn through the regular viewing of so much suffering and evil born by others to have less fear and better endure our own. $)^{34}$

Tragedy is particularly effective in providing consolation for the inevitable trials of life because it portrays the endurance of ill fate on a large scale. The justification for the focus on members of the political elite in tragedy does not draw on traditional rhetorical standards of decorum or the demands of the genus sublime, but instead on the greater communicative scope, the greater extension of potential addresses, such figures possess. Saul's disobedience and fate are a lesson for tyrants in particular, but also for the human in general. It is Saul's fate in particular-his loss of seven sons-that stands in the

See Schäfer, 'Versuch über Souveränität und Moral im barocken Trauerspiel', esp. pp. 387393 .

33 See Gryphius, Gesamtausgabe der deutschsprachigen Werke, vol. 6, p. 129.

34 Opitz, Weltliche Poemata, vol. 1, p. 315.
} 
focus of Gryphius's conception of the play's larger didactic import. This is, of course, a significant change in emphasis from Vondel's play, at the center of which stands King David and his deliberations and distress over the sacrifice of Saul's descendants. But the shift from David to Saul coheres with the double assignment of tragedy to both tyrants in particular and man in general.

The liberty Gryphius took with the Vondel template draws on a tradition in sixteenth- and early seventeenth-century German drama of identifying Saul as a tyrant fitting for tragedy. ${ }^{35}$ At least two tragedies that predate GryphiusHans Sachs's Tragedi König Sauls mit Verfolgung Davids (1557) and Wolfhart Spangenberg's Saul. Ein Klegliche Tragoedia/vom Gottlosen könige Saul/ vnd seinem schrecklichen vntergang (1606) — counterpose David and Saul like good and evil and take Saul as the model of a vicious and tyrannical king. In Spangenberg's play, for instance, Saul develops an ultimately self-destructive jealousy of David's military success and suspects the young hero of seeking to depose him. 'Do you not aspire to the king's throne, so that you may already rule in my stead?' ('Trachtest du nicht nachs Königs Thron | An mein stat zu regieren schon?') Saul asks at the turning point of the play, the first scene of the third act. ${ }^{36}$ From this moment on, Saul is launched into a downward spiral of paranoid aggression that culminates in him falling on his own sword. The tragedy establishes a direct connection between Saul's violent fear of losing political power and his abandonment of religious virtue. The speaker of the epilogue claims that Saul's actions demonstrate that a 'vengeful, envious heart, is quickly captured by the devil.' ('Wie eyn Rachgirig / Neidisch Hertz / Vom Teuffel balt wird eingenommen.') ${ }^{37}$ Gryphius, too, will take Saul as doomed for his tyranny and moral corruption. In this respect, both authors writing in the German language fall in lockstep with conventional portrayals of Saul in the neo-Latin dramatic tradition. ${ }^{38}$

If my emphasis on the political thrust of Gryphius's emended translation seems overstretched, consider the second use of the Vondel's template that appeared about twenty years after Gryphius undertook his. In this case, David Elias Heidenreich published a Trauerspiel entitled Rache zu Gibeon oder Die Sieben Brüder aus dem Hause Sauls in 1662, to which he appends the subtitle

36 For a reprint of the play see Wolfhart Spangenberg, Sämtliche Werke, ed. András Vizkelety (Berlin: Walter de Gruyter, 1975), vol. 2, pp. 273-412. See esp. p. 337. See Wolfhart Spangenberg, Sämliche Werke, vol. 2, p. 411.

38 For instance: Theodorus Rhodius, Saul (Asselheim 1615); Michael Virdung, Saulus (Jena 1595); Edmund Campion, Saulus (written between 1574 and 1580 in Prague). 
'mostly according to [or after] the Dutch of Joost van Vondel. ${ }^{39}$ Signal differences to Vondel and Gryphius are immediately evident: this play is in prose, it introduces an abundance of additional scene-divisions, and it amplifies the portrayal of violence. At the same time, the language of the play betrays the significant use Heidenreich made of Gryphius's adaptation, which he must have accessed in manuscript form. ${ }^{40}$ I wish to isolate a single passage from the play, which indicates the peculiar balance between adherence to convention and adaptive liberty that characterizes the processes of transfer that give rise to Trauerspiel. For Heidenreich's play departs even further from the Dutch original, as he radicalizes Gryphius's moral-political reframing. I have in mind the final speech delivered by the captain of the royal guard, spoken 'to the audience' ['gegen das Volck'] ${ }^{41}$ The terms of Gryphius's prologue, omitted from Heidenreich's play (and, of course, absent from Vondel's), reappear here at the conclusion in slightly varied form:

Spiegelt euch ihr Blut=dürstigen! Spiegelt euch ihr Tyrannen! Spiegelt euch / die ihr anfanget groß zu werden! [...] Verfluchte Tyranney! hütet euch davor / Ihr Grossen der Welt. Trifft euch nicht das Wetter / das dieses Laster ahndet / so wird es doch der nach Euch kömmt empfinden. Gott ist immittelst gerecht. Der erniedriget und erhöhet. Der lasse das Haus David ewig grünen und blühen.

(See your reflection you bloodthirsty rulers! See your reflection you tyrants. See your reflection, those of you beginning to become powerful! Damned tyranny! Protect yourselves from it, you powerful men of the world. Even if the weather does not strike you that punishes this vice, those who come after you will come to feel it. God is in the meantime just. He brings down and raises. May he let the house of David eternally thrive and bloom. $)^{42}$

The echoes of Gryphius's text are unmistakable. The play addresses itself to tyrants, aspiring and actual, whose ruthless thirst for power leads them to disre-

39 See title page to David Elias Heidenreich, Rache zu Gibeon oder Die Sieben Brüder aus dem Hause Sauls. Meist nach dem Holländischen Josts van Vondel (Görlitz: Johannes Candisius 1662).

40 This has been discussed in the editor's preface to Egbert Krispyn (ed.), Joost van den Vondel Gebroeders 1648, Andreas Gryphius Die Gibeoniter 169o, David Elias Heidenreich Die Rache zu Gibeon (Bern: Peter Lang, 1987), pp. 5-69, esp. pp. 55-56.

41 Heidenreich, Rache zu Gibeon, p. 102.

42 See Heidenreich, Rache zu Gibeon, p. 102. 
gard moral considerations. Whereas Gryphius calls the eternally-damned Saul onto the stage as implicit evidence of the fate that befalls tyrants, Heidenreich makes verbally explicit the providential order the play is meant to illustrate. The claim that the play demonstrates divine vengeance helps explain the most striking feature of Heidenreich's play: the extensive verbal treatment of the sacrifice of the seven descendants of Saul and the visual display of their crucifixion. ${ }^{43}$ This modification is more than a testament to Heidenreich's brutal indifference to the classicizing standards of Vondel's tragedy, which dictated that such violence must take place offstage and be related only through a messenger's report. The alteration is an indication that Heidenreich, following Gryphius, took the act of divine retribution, the belated punishment of Saul's tyrannical deeds, as the real focus of the play. David's vexed deliberations whether or not to hand over the seven to sure death (Vondel's main interest) fade into the background, for Heidenreich clearly regards them as secondary to the eschatological, nearly casuistic frame. The vivid portrayal of the hangings is the visual realization of the promise voiced in the above quoted passage: even if acts of tyranny are not immediately punished, divine punishment will be visited upon a future generation. Heidenreich employs the gruesome display as vivid evidence of the inevitability of divine retribution.

\section{Case 2: Kormart's Maria Stuart and Vondel's Maria Stuart}

Extreme violence is also manifest in the second cluster of geographical and linguistic transfers I wish to discuss. The point of departure shall be the Trauerspiel Christophorus Kormart published in 1673 under the title Maria Stuart Oder Gemarterte Majestät. ${ }^{44}$ The play professes to be 'after' or 'according to' Vondel's 1646 Maria Stuart of Gemartelde majesteit, but the changes it introduces penetrate to the core of the original construction. Without question, Vondel's play about the Queen of Scots, Mary Stuart or Tortured Majesty, is as much a statement about the injustice of beheading a sovereign as it is about his Catholic sympathies. ${ }^{45}$ Vondel converted to Catholicism a few years before he wrote the

43 See Heidenreich, Rache zu Gibeon, pp. 90-94 and p. 99.

44 Christoph Kormart, Maria Stuart oder Gemarterte Majestät (Halle:Johann Fick Witwe und Erben, 1673).

45 See Judith Pollmann, 'Vondel's Religion' and James A. Parente, Jr. and Jan Bloemendal, 'The Humanist Tradition-Maria Stuart (1646)', in Bloemendal and Korsten, Joost van den Vondel, pp. 85-100 and pp. 341-358. 
martyr play, and he developed a sharply asymmetrical design in order to establish the wrongfulness of the virtuous heroine's death. The play's dedication to Lord Edward, Count Palatine and Duke of Bavaria who also happened to be the great-grandson of Mary Stuart herself, compares the beheaded queen to Moses and Christ and characterizes her death as a martyrdom on behalf of her catholic faith. The play was initially published anonymously, but an error of the publisher made Vondel's name public; its offensiveness to the Calvinist authorities earned him an immediate fine. ${ }^{46}$

As in the previous cluster of adaptations, the selection of this Vondel play for adaptation is striking. The play constitutes a surprising choice in virtue of its strong religious polemic and its focus on the English and Scottish monarchies. The topic was in many respects less readily accessible than the Biblical and ancient historical narratives that predominately stand at the center of Trauerspiel. But this was neither the first nor the last time that German playwrights would turn to the House of Stuart and bloody conflict within the two kingdoms of the British Isles. From among the abundance of contemporary bloody events, including the devastating conflicts of the Thirty Years' War, only the deaths of Charles and Mary Stuart became the subject of Trauerspiel. Two factors seem to have conspired to make this subject particularly attractive: on the one hand, the recognition of English affairs of state as possessing adequate gravity and at the same time the use of venerated, which is to say Dutch, contemporary dramatizations of the very same history. These two preconditions allow English royal history to stand alongside plays primarily populated by the venerated personalities of Hebrew, Roman, and Byzantine history.

However, German writers did not generally feel a stronger affinity to English history than to that of other European nations. Nor is it the case that Kormart's adaptation of Vondel was more than an expression of personal favor for Dutch neo-classical drama. In considering this play, we instead find ourselves in the midst of a larger itinerary of appropriations, and adaptations, of which the Kormart's Maria Stuart constitutes a station along the way. In the preface to his play, Kormart situates himself in a lineage founded by one of the most prominent German authors of his day, none other than Gryphius. His deployment of English royal history as the subject for Trauerspiel was licensed by an anterior authority: Gryphius's publication of Ermordete Majestät oder Carolus Stuardus (1657, revised and significantly expanded 1663). Gryphius established a pedigree, which includes Kormart as well as a number of other playwrights, who

46 See Parente, Jr. and Bloemendal, 'The Humanist Tradition—Maria Stuart (1646)', pp. 341344 . 
made the Stuart monarchy the subject of Trauerspiel. Other members of the lineage include Johannes Riemer's Von Staats Eiffer from 1681 and August Adolf von Haugwitz's Schuldige Unschuld oder Maria Stuarda from 1683. Whereas the Haugwitz play shows no signs of familiarity with the Dutch play and its German adaptation, it draws heavily on Gryphius's earlier portrayal of the House of Stuart. ${ }^{47}$ Riemer, meanwhile, acknowledges that some lines of his play are lifted from Kormart and Vondel while making no mention of Gryphius. Nonetheless, it was Gryphius who first made the Stuart monarchy a candidate for Trauerspiel and who set into motion a process that brought forth adaptations and original dramas alike with the same thematic focus. This generally unacknowledged fact is particularly important because Gryphius is often treated as one of the two lone stars in seventeenth-century drama that essentially disappeared from the heavens of great literary figures until being rediscovered in the early twentieth century. In truth, though, he had a tremendous impact on seventeenth-century playmaking; similarly the success of his Carolus Stuardus did not concern the theory of political sovereignty (the favored lens for viewing the play in recent scholarship), but instead in the line of other Stuart plays it spawned.

I just asserted that Kormart adverts to Gryphius's tragedy on the Stuart monarchy in order to legitimize his own undertaking. The reference is, as such, unnecessary since the events depicted in Gryphius's Trauerspiel take place two generations later than in Kormart's; the purpose here is, rather, strategic. Citing a passage from the second prefatory monologue in the first edition of Gryphius's play, which brings the ghost of Maria Stuart onto the stage, ${ }^{48}$ Kormart draws on an authoritative source to support the highly sympathetic portrait of Mary he will paint. In Gryphius's rendering, Maria's brief appearance in the play serves to describe her fatal misfortune and to introduce an antecedent instance of the grave injustice Charles suffers. Of the essence to both the story of Mary and Charles Stuart was the controversial issue whether a political subject can bring a monarch to trial and condemn her to death. Both Kormart and Gryphius endorse the view, expressed by the latter, that only God 'appoints and judges princes. ${ }^{49}$ In the background of the Vondel adaptation, then, is another

47 August Adolf von Haugwitz, Schuldige Unschuld oder Maria Stuarda: Faksimiledrucknach der Ausgabe von 1683, ed. Robert R. Heitner (Bern: Peter Lang, 1974).

48 For the entire monologue, see Andreas Gryphius, Gesamtausgabe der deutschsprachigen Werke, vol. 4, pp. 6-9. The passage was excised when Gryphius reworked the play for a second edition.

The passage is cited on the fourth unnumbered page in the preface to Kormart's play. The 
martyr play, which aims to demonstrate the divine authority with which Mary and Charles Stuart respectively rule and, by contrast, vilify those responsible for deposing the king, especially the anti-royalist radical Puritan sects. ${ }^{50}$

Given the decisive role it plays in shaping the later dramatizations of the Stuart monarchy, a few words on Gryphius's play are in order. His advocacy of monarchical authority, tinged though it was by his sensitivity to its violent abuses, led him to portray the beheading of Mary and Charles Stuart as the infractions of a misdirected notion of earthly justice against the superseding divine authority of absolute monarchy. The supermundane mandate of Charles's rule is dramatized according to a strict typological schema, based in no small part on the self-stylization as martyr in the image of Christ propagated in the king's Eikon Basilike. ${ }^{51}$ The politically tendentious character of Gryphius's Trauerspiel, enhanced through references to Salmasius Defensio Regia pro Carolo I and Philip von Zesens Der verschmähete / doch wieder erhöhete Majestäht, among others, is rooted within his concrete historical situation. Its dedication to Princess Elizabeth of the Palatinate, a relative of Charles Stuart himself, is an indication that the author intended his Trauerspiel as a mechanism for soliciting support against the revolutionary government led by Oliver Cromwell. Support for this design is provided by Gryphius in the extensive apparatus with quotations from ancient and modern sources in Latin, Italian and German, which supplies his defense of Charles with ostensibly authoritative historical information and legal doctrine. Although his aspiration to historical fidelity leads him to lend an almost convincing plausibility to the opposition

original quotation can be found in Andreas Gryphius, Gesamtausgabe der deutschsprachigen Werke, vol. 4, p. 8 .

$5^{0}$ This is particularly evident in Gryphius's portrayal of the figure Hugo Peter, the ecclesiastical rabble-rouser and military leader.

$5^{1}$ The typological backdrop to the play has been emphasized by Albrecht Schöne, 'Ermordete Majestät. Oder Carolus Stuardus König von Groß Britannien', in Gerhard Kaiser (ed.), Die Dramen des Andreas Gryphius, pp. 117-169. With respect to Gryphius, see also KarlHeinz Habersetzer, Politische Typologie und dramatisches Exemplum: Studien zum historisch-ästhetischen Horizont des barocken Trauerspiels am Beispiel von Andreas Gryphius' Carolus Stuardus und Papinianus (Stuttgart: J.B. Metzler Verlag, 1985), pp. 1-42. For the broader historical context, see Helmer Helmers, The Royalist Republic: Literature, Politics and Religion in the Anglo-Dutch Public Sphere (1639-1660), unpublished dissertation, Leiden, 2011. See also Nigel Smith, 'Theatrum Mundi and the Politics of Rebellion in Seventeenth Century Drama', in Björn Quiring (ed.), 'If Then the World a Theatre Present ...': Revisions of the Theatrum Mundi Metaphor in Early Modern England (Berlin: Walter de Gruyter, 2014), pp. 199-220. 
to Charles $\mathrm{I}^{52}$ the formal design of the play weights the historical events in such a way as to make the monarch's beheading appear an illegal and irreligious infraction. To achieve this end, the dramaturgy of events-which is to say, the manner of presentation according to which the historical sequence unfolds - is remarkably monolithic and flat. From the opening ghost monologues to the chorus of assassinated kings to the concluding speech by the allegory of revenge, the play portrays the deposing of the king as an act that sets loose intractable and potentially interminable violence. In addition to the question of the king's divine right, the play concentrates attention squarely on questions of political stability. The source of its endangerment, as the dramatic action spells out, is the unlawful revolt against Charles. In addition to the question of the king's divine right, Gryphius focuses attention particularly on the anarchic consequences of revolt.

There is a close formal affinity between the asymmetrical design of Gryphius's Trauerspiel, which ensures the higher unassailability of the martyr king, and Vondel's rendering of Mary Stuart's fate. In both cases, the uneven organization of the political conflict provides the structural precondition for transmitting the play's political and religious message. One must notice this basic organizational feature of both dramas in order to grasp just how extreme Kormart's Maria Stuart departs from the template provided by the Dutch Vondel play. Despite the professed debts to two martyr plays, Kormart in fact creates something strikingly different from either of his forebears. Instead of rendering one political party in the play inviolable, Kormart brings the lamentable state of two queens [zweyer Königinnen Trauer=Stand]' onto the stage. ${ }^{53}$ His portrayal of Elizabeth and Mary as both 'queens worthy of the highest renown,, 54 is motivated by his dedication to 'the truth of history'55 and avowed disfavor for polemic and bias. In contradistinction to Vondel, then, he consults 'the judgments that appeared the most veracious and judicious from both sides' and avoids 'the suspicious besmirching of such high heads. ${ }^{56}$ His even-handed approach 'deviates from the assignments of the distinguished Dutch poet ${ }^{57}$ but with the purpose of 'following the predilections of different spectators. ${ }^{58}$ Kor-

$5^{2}$ This ambiguity has been exploited in the reading of the play in Albrecht Koschorke a.o., Der fiktive Staat, pp. 141-150.

53 Kormart, Maria Stuart oder Gemarterte Majestät, p. 2 of unpaginated dedication.

54 Ibid., p. 4.

55 Ibid., p. 2.

56 Ibid., p. 3.

57 Ibid., p. 5 .

$5^{8}$ Ibid., p. 6. 
mart's deviations are, at bottom, a complete transformation of the architectural principles that shape Vondel's play, adding additional figures and disrupting the asymmetrical martyrology.

Much as in the adaptations of Gebroeders I discussed above, Kormart alters the thematic focus in order to accommodate the geographical and linguistic transfer. In fact, the proportions and content of Kormart's deviate so radically from Vondel's play that the Vondel template nearly vanishes. The most significant changes consist in Kormart's introduction of an expansive role for Elizabeth, a figure entirely absent from the Dutch original. On the stage, she becomes the mouthpiece of controversial political-philosophical principles. To wit, her deliberations in the play bear on the question whether the preservation of the political order provides the allowance for beheading a member of the royalty. The central issue is what moral allowances are provided by the need to secure the state and its population. ${ }^{59}$ When Kormart inserts Elizabeth and therewith inserts extensive deliberations between the English queen and her advisors, who encourage her to behead her cousin in order to preserve her own rule and maintain political stability, Vondel's play balloons into a text of approximately four times its original length. It is particularly remarkable in light of the asymmetrical design of Vondel's martyr play that both Mary and Elizabeth are portrayed as thoroughly noble: Mary advocates a pure 'conscience' as the foundation of justice and 'the holy law', 60 whereas Elizabeth as a proponent of 'justice, moderation, wisdom, and bravery.'61 The real crux of the play, then, is the question what course of action is justified in order to preserve the 'peace of the state and security.' ${ }^{\prime 2}$ Again and again throughout the course of the play, Elizabeth and her advisors return to the question whether it is permissible and advisable to behead the Scottish queen in order to 'secure the state. ${ }^{63}$ Elizabeth appears in the grips of indecision for almost the entire play, even making an unsuccessful attempt to halt the execution, after she has issued the sentence. ${ }^{64}$ By no means selfishly fixated on her own survival or clasping fearfully to the throne, Elizabeth is a noble queen undecided whether one 'must pur-

59 As Michael Foucault has shown, the notion of security was central to seventeenth-century political discourse. See Michel Foucault, Security, Territory, Population: Lectures at the Collège de France 1977-1978, transl. Graham Burchell (New York: Picador, 2009), esp. pp. 186.

6o Kormart, Maria Stuart oder Gemarterte Majestät, p. 10 and 27.

61 Ibid., p. $5^{2}$.

62 Ibid., p. 26.

63 Ibid., p. 59 .

64 Ibid., pp. 114-116. 
chase security through the spilling of noble blood. 65 When at the end of the final act (in the ultimate un-classicizing gesture, the fourth of the play), Mary is beheaded onstage, Elizabeth is anything but a villain. Having desperately sought to rescue her cousin from death, her culpability is uncertain. Considered in terms of the formal design of the play, such obscuring of moral responsibility serves a double purpose. Most obviously, it allows both queens to emerge in a positive light. Furthermore, the conceptual consequence of the positive portrayal of Elizabeth's moral fabric positions her at some remove from the morally ambiguous notion of the security of state.

The insistence upon the interlacement of religion and politics - as well as the fatal consequences of their disentanglement-is nowhere more evident than the final employment of the Vondel template I wish to discuss: a play Von Staats=Eifer, published in 1681 as the fourth 'discourse' in Johannes Riemer's (1648-1714) Der Regenten Bester Hoff=Meister Oder Lustiger Hoff=Parnassus. ${ }^{6}$ In its introduction, the play professes to have made use of Kormart's adaptation of Vondel in making a play that is meant to demonstrate that 'religious zeal can never be removed from the zeal of government and state [kan der Religions=Eiffer / von dem Eiffer der Regierung und des Staats nicht entfernet seyn]. ${ }^{67}$ The additional degree of removal from Vondel's original composition is evident throughout Riemer's play. The alterations range from the inclusion of an irreverent stage fool to the excision of lengthy legal debates introduced by Kormart to an enhancement of Elizabeth's responsibility for Mary's beheading. The key issue in this play is not the religious divide between the Roman Catholic Queen of Scots and her Protestant English cousin, though that too makes an appearance in the early scenes. It is, rather, the queen's self-interested struggle for political survival. As in Kormart's rendering, Elizabeth ultimately heeds her counselors' advice that Mary must die because of her conviction that any other course of action would endanger her own life and the stability of the English kingdom. As in Kormart, Riemer characterizes Elizabeth in sympathetic terms, including the belated and hence failed attempt at a pardon. And again, the decision to behead is cast as a political decision made independent of proper moral consideration.

65 Ibid., p. 118.

66 Reprinted in Johannes Riemer, Werke, ed. Helmut Krause (Berlin: Walter de Gruyter, 1984), vol. 2, pp. 471-519.

67 Riemer, Werke, vol, 2, p. 474. 


\section{Toward the International Migration of Genre}

By contrast with Vondel's original play, neither Kormart nor Riemer place emphasis on sectarian religious conflict, but instead on the abandonment of religiously inflected moral considerations tout court. Both cast aspersion at actions pursued on the basis of political exigency. Absent from all the plays I have discussed is a robust meditation on the theory of political sovereignty, the very matter that since Benjamin's Habilitationsschrift has been taken as the hallmark of the German baroque Trauerspiel. When these plays thematize the prerogative of a monarch, they do so not with an eye toward 'the state of exception' or toward Jean Bodin's absolutist treatise, but instead toward the (theoretically naïve) perils of political decision-making when severed from the sphere of moral values. This has surprising consequences. For instance, concerning the historical trend described most influentially by Reinhart Kosselleck in his powerfully argued book Kritik und Krise, one can see that these plays concentrate on the overarching trend that increasingly separates political sovereignty from morality. ${ }^{68}$ All the plays I have touched on use the Vondel template to bring Trauerspiel into existence in ways that demonstrate the pitfalls of such a historical development. What is more, the condemnation of a distinct system of political action and its justification brings with it a division of moral considerations from religious ones. Against expectations, none of these plays identifies moral shortcomings with religious partisanship, as the Vondel template encourages. Even though all of the writers I have considered were Lutherans, they, unlike Vondel, do not make their plays into battlegrounds for the conflict between the Reformed and Catholic church, but instead focus on a political sphere disconnected from the teachings of the church altogether. In this respect, the religiously motivated internecine conflicts of the Thirty Years' War may be thought of as the hinge on which the political content of Trauerspiel turns.

There can be no doubt that Vondel became something altogether different in the German context than in the Dutch one. He was not a religiously or politically controversial figure; he was not a neo-classicist or philhellene; and he was not an author of plays that demanded faithful translation. Instead, he became a template for making Trauerspiel—a source for a basic storyline,

68 See Reinhart Koselleck, Kritik und Krise: Eine Studie zur Pathogenese der bürgerlichen Welt (Frankfurt am Main: Suhrkamp Taschenbuch Wissenschaft, 1973), esp. pp. 11-39. See also the astute observations in Niklaus Luhmann, 'Die Ausdifferenzierung der Religion', in Niklas Luhmann, Gesellschaftsstruktur und Semantik (Frankfurt am Main: Suhrkamp Taschenbuch Wissenschaft, 1993), vol. 3, pp. 259-357, esp. pp. 300-309. 
a reservoir of turns of phrase, a model for dramaturgical arrangement. This template allowed for the creation of something altogether new and different once it got caught up in the ongoing project of establishing German as a poetic language. For this was anything but a project of autodidactism. To make German poetry was to draw on external resources, antecedent models, and contemporary parallels. The still inchoate endeavor to bring forth a national literature-for Opitz's heritage is nothing less than that — was always already a project filled with deracination and appropriations. If German Trauerspiel became something unique and different, it did so in working with templates lifted from the broader European context.

Over recent decades, literary studies have resurrected a conceptual and terminological shift that Goethe introduced in the early decades of the nineteenth century, namely the claim that an epoch world literature is currently supplanting an epoch of national literature. As scholars have returned to Goethe's terminology as well as its elaboration and expansion by Marx, a troubling ambiguity has repeatedly reared its head. It is not always clear whether the denomination world literature refers to an epoch of critical analysis or an epoch of literary production. The most eminent Anglo-American contemporary critics such as Emily Apter, David Damrosch, Wai Chee Dimock, Franco Moretti, and Gayatri Spivak have in polemical yet often deftly argued essays and books trod on both sides of this line. ${ }^{69}$ I mention these recent discussions because the case of Trauerspiel in the seventeenth century would suggest that one should perhaps retain the terms world and national literature in a relationship of interdependence. To be sure, beginning with Opitz in the seventeenth century, the project to establish a German national literature persisted as a culturally salient force. But this project itself took place within a larger forum of European vernacular literatures, from which templates like Vondel and Treurspel could be borrowed and, in time, transformed. The permeable boundaries of German literature should not be taken as a deficiency of the ever-belated German context, but instead as the instigating reason for the national literary project at all as well as the channels through which templates for making poetry were transmitted. German Trauerspiel was always already both a German and an international affair.

69 Among the many recent publications on this theme see: Emily Apter, Against World Literature: On the Politics of Untranslatability (London: Verso, 2013); David Damrosch, What is World Literature? (Princeton: Princeton University Press, 2003); Wai Chee Dimock, 'Literature for the Planet', PMLA 116 (2001), 173-188; Franco Moretti, Distant Reading (London: Verso, 2013); Gayatri Spivak, Death of a Discipline (New York: Columbia University Press, 2003). 
One final point: the international circulation of plays that I have been tracking does not fit with an ennobled concept of literature. The adaptations of the Vondel template are not part of the formation of a literary tradition; they are not concerned with the forging of a heritage and passing down great texts. While Vondel has certainly achieved distinction as the greatest of Dutch dramatists, the adaptations I have been dealing with belong to the large masses of texts that passed into oblivion until their rediscovery in the discourse of literary scholarship. In seeing how this Dutch dramatist, who would later become a national hero, served a template for the making of Trauerspiel in the seventeenth century, then, we do not get a glimpse of forgotten great works. Instead, we attain a sharper sense of the concrete practice of making poetry in the German-speaking lands in the Baroque age.

\section{Further Reading}

Bornemann, Ulrich, Anlehnung und Abgrenzung: Untersuchungen zur Rezeption der niederländischen Literatur in der deutschen Dichtungsreform des siebzehnten Jahrhunderts (Assen: Van Gorcum, 1976).

Gemert, Guillaume van, 'Between Disregard and Political Mobilization - Vondel as a Playwright in Contemporary European Context: England, France and the German Lands', in Jan Bloemendal and Franz-Willem Korsten (eds.), Joost van den Vondel (1587-1679): Dutch Playwright in the Golden Age (Leiden: Brill, 2012), pp. 171-198.

Menke, Bettine. Das Trauerspiel-Buch: Der Souverän, Das Trauerspiel, Konstellationen, Ruinen (Bielefeld: Transcript, 2010).

Newman, Jane O., Benjamin's Library: Modernity, Nation, and the Baroque. Ithaca, NY: Cornell UP: Cornell u Library, 2011.

Wild, Christopher J. Theater der Keuschheit-Keuschheit des Theaters: Zu einer Geschichte der (Anti-)Theatralität von Gryphius bis Kleist (Freiburg im Breisgau: Rombach, 2003). 